University of Nebraska - Lincoln

DigitalCommons@University of Nebraska - Lincoln

Publications from USDA-ARS / UNL Faculty

U.S. Department of Agriculture: Agricultural

Research Service, Lincoln, Nebraska

2011

Improving in-season nitrogen recommendations for maize using an active sensor

J. Schmidt

USDA - Agricultural Research Service, john.schmidt@ars.usda.gov

D. Beegle

Pennsylvania State University

Q. Q. Zhu

Pennsylvania State University

R. Sripada

Monsanto Company

Follow this and additional works at: https://digitalcommons.unl.edu/usdaarsfacpub

Part of the Agricultural Science Commons

Schmidt, J.; Beegle, D.; Q. Zhu, Q.; and Sripada, R., "Improving in-season nitrogen recommendations for maize using an active sensor" (2011). Publications from USDA-ARS / UNL Faculty. 874.

https://digitalcommons.unl.edu/usdaarsfacpub/874

This Article is brought to you for free and open access by the U.S. Department of Agriculture: Agricultural Research Service, Lincoln, Nebraska at DigitalCommons@University of Nebraska - Lincoln. It has been accepted for inclusion in Publications from USDA-ARS / UNL Faculty by an authorized administrator of DigitalCommons@University of Nebraska - Lincoln. 


\title{
Improving in-season nitrogen recommendations for maize using an active sensor ${ }^{\text {is }}$
}

\author{
J. Schmidt ${ }^{\mathrm{a}, *}$, D. Beegle ${ }^{\mathrm{b}}$, Q. Zhu $^{\mathrm{b}}$, R. Sripada ${ }^{\mathrm{c}}$ \\ a USDA - Agricultural Research Service, Pasture Systems E Watershed Management Research, Unit, Building 3702 Curtin Road, University Park, PA 16802, USA \\ ${ }^{\mathrm{b}}$ The Pennsylvania State University, Department of Crop and Soil Sciences, 116 ASI Building, University Park, PA 16802, USA \\ c Monsanto Company, Technology Development, Mail Stop NC4G, 800 N. Lindbergh Blvd., St., Louis, MO 63167, USA
}

\section{A R T I C L E I N F O}

\section{Article history:}

Received 27 July 2010

Received in revised form 8 September 2010

Accepted 9 September 2010

\section{Keywords:}

Remote sensing

Precision agriculture

Spatial variability

\begin{abstract}
A B S T R A C T
An active crop canopy reflectance sensor could be used to increase $\mathrm{N}$-use efficiency in maize (Zea mays $\mathrm{L}$.), if temporal and spatial variability in soil $\mathrm{N}$ availability and plant demand are adequately accounted for with an in-season $\mathrm{N}$ application. Our objective was to evaluate the success of using an active canopy sensor for developing maize $\mathrm{N}$ recommendations. This study was conducted in 21 farmers' fields from 2007 to 2009, representing the maize production regions of east central and southeastern Pennsylvania, USA. Four blocks at each site included seven sidedress $\mathrm{N}$ rates $\left(0-280 \mathrm{~kg} \mathrm{~N} \mathrm{ha}^{-1}\right)$ and one at-planting $\mathrm{N}$ rate of $280 \mathrm{~kg} \mathrm{~N} \mathrm{ha}^{-1}$. Canopy reflectance in the $590 \mathrm{~nm}$ and $880 \mathrm{~nm}$ wavelengths, soil samples, chlorophyll meter (SPAD) measurements and above-ground biomass were collected at the 6 th-7th-leaf growth stage (V6-V7). Relative amber normalized difference vegetative index $\left(\mathrm{ANDVI}_{\text {relative }}\right)$ and relative SPAD $\left(S P A D_{\text {relative }}\right)$ were determined based on the relative measurements from the zero sidedress treatment to the $280 \mathrm{~kg} \mathrm{~N} \mathrm{ha}^{-1}$ at-planting treatment. Observations from the current study were compared to relationships between economic optimum $\mathrm{N}$ rate (EONR) and $\mathrm{ANDVI}_{\text {relative, }}$, presidedress $\mathrm{NO}_{3}$ test (PSNT), or $S P A D_{\text {relative }}$ that were developed from a previous study. These comparisons were based on an absolute mean difference (AMD) between observed EONR and the previously determined predicted relationships.

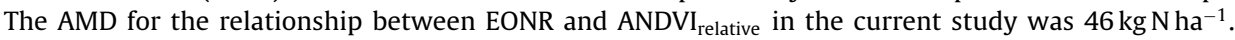
Neither the PSNT (AMD $\left.=66 \mathrm{~kg} \mathrm{~N} \mathrm{ha}^{-1}\right)$ nor the $\operatorname{SPAD}_{\text {relative }}\left(A M D=72 \mathrm{~kg} \mathrm{~N} \mathrm{ha}^{-1}\right.$ ) provided as good an indicator of EONR. When using all the observations from the two studies for the relationships between EONR and the various measurements, $\operatorname{ANDVI}_{\text {relative }}\left(R^{2}=0.65\right)$ provided a better estimate of EONR than PSNT

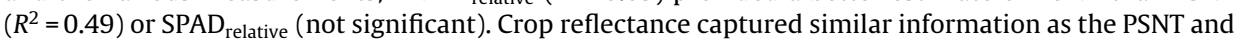

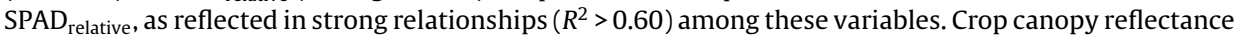

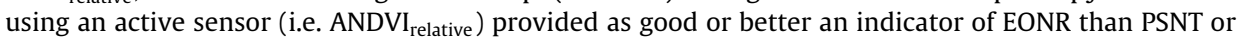

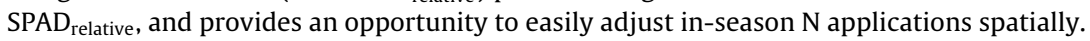

Published by Elsevier B.V.

\section{Introduction}

As the world population approaches seven billion, maize (Zea mays $\mathrm{L}$ ) production without the adverse environmental impacts of $\mathrm{N}$ fertilizer will be essential to sustainable agricultural systems. One of the major challenges related to maize production today is the adverse environmental impacts associated with the large amounts

Abbreviations: AASL, agricultural analytical services laboratory; EONR, economic optimum nitrogen rate; ANDVI, amber normalized difference vegetative index; PPNT, preplant nitrate test; PSNT, presidedress nitrate test; SPAD, chlorophyll meter; UAN, urea-ammonium-nitrate.

is Trade or manufacturers' names mentioned in the paper are for information only and do not constitute endorsement, recommendation, or exclusion by the USDAARS.

* Corresponding author. Tel.: +1 8148630947.

E-mail address: john.schmidt@ars.usda.gov (J. Schmidt). of $\mathrm{N}$ fertilizer applied to this crop. Nitrogen fertilizer recovered in the above-ground plant biomass is less than $40 \%$ of the amount applied in the same year as the crop grown, as represented by the major maize producing areas of the United States (Cassman et al., 2002). Nitrogen fertilizer in excess of the amount required by maize can be readily leached through soil as $\mathrm{NO}_{3}$ and adversely impacts ground and surface waters (Hong et al., 2007). With elevated $\mathrm{NO}_{3}$ levels in ground and surface waters, human health risks are increased and premature eutrophication of surface waters contributes to a cascade of negative environmental impacts on aquatic life, fishing and tourist industries, and drinking water quality.

After the 1940s when the availability of $\mathrm{N}$ fertilizer increased dramatically through the Haber-Bosch process, $\mathrm{N}$ fertilizer recommendations were developed to facilitate the appropriate use by farmers of this new and cheap source of $\mathrm{N}$ fertilizer. Many $\mathrm{N}$ fertilizer recommendations in the USA were developed based on a model in which yield goal was the defining independent variable. 
While some states still rely on this approach (e.g., Buchholz et al., 1993; Shapiro et al., 2003; Beegle, 2008b), there has been a recent move towards developing $\mathrm{N}$ recommendations that better reflect economic return (e.g., Sawyer et al., 2006; Dellinger et al., 2008). Maximum yield, i.e. yield goal, does not usually correspond well with the economic optimum N rate (EONR; Fox and Piekielek, 1995; Vanotti and Bundy, 1994), and EONR represents best return for the farmer and corresponds with minimal $\mathrm{N}$ losses to the environment (Hong et al., 2007; Sripada et al., 2008).

To address the temporal needs of a growing maize crop, appropriate $\mathrm{N}$ fertilizer rates should be applied during the early part of the growing season, just before or during the period of rapid vegetative growth (Schepers et al., 1995). Several methods that are available for making or adjusting $\mathrm{N}$ recommendations for maize include: a presidedress nitrate test (PSNT), a chlorophyll meter (SPAD), and a preplant $\mathrm{NO}_{3}$ test (PPNT). Detailed description about these different methods can be found in previous studies (Magdoff, 1991; Varvel et al., 1997; Schmidt et al., 2009). These methods are generally implemented for a field- or farm-specific $\mathrm{N}$ recommendation; consequently, the spatial variability of $\mathrm{N}$ requirement within a field is usually not considered with these methods. The quantity of sampling and/or analyzing samples would be time consuming and expensive for a spatially variable application (Blackmer and Schepers, 1996; Schmidt et al., 2009). In addition, N recommendation algorithms developed for whole-field management may not improve $\mathrm{N}$ management when extrapolated to a within-field scale (Ferguson et al., 2002).

While the spatial variability in crop demand and soil supplying capacity for nutrients has long been recognized, the recent availability of precision technologies has encouraged researchers to pursue methods with which to capture the appropriate information for spatially variable N recommendations (e.g., Raun et al., 2002; Blackmer et al., 1995; Scharf et al., 2005; Schmidt et al., 2007; Zhu et al., 2009). Remote sensing techniques can be used to detect $N$ deficiency in maize (Blackmer et al., 1995), and the density of spatial information available using this technology is particularly attractive for developing spatially variable $\mathrm{N}$ recommendations. Active sensors that can be mounted on a $\mathrm{N}$ applicator are commercially available, and recent research suggests that these sensors can be used for developing $\mathrm{N}$ recommendations for maize (Dellinger et al., 2008; Schmidt et al., 2009). While this latest research has correlated EONR directly to canopy reflectance, the results were based on a field study from a relatively small geographic region. Whether the developed algorithm could be extrapolated to a larger geographic region was undetermined. This earlier study (Dellinger et al., 2008; Schmidt et al., 2009) also showed that the information obtained with the active sensor was as well correlated to EONR as to PSNT or SPAD for the fields evaluated in Centre County, Pennsylvania, USA. Developing an algorithm for making maize $\mathrm{N}$ recommendations based on the sensor to be used in a larger region will be essential to successfully transferring this technology for variable $\mathrm{N}$ applications to maize.

The objective of the current study was to (i) evaluate the relationship between EONR and maize crop canopy reflectance measured by an active sensor - Crop Circle ACS-210 (Holland Scientific, Lincoln, NE), and (ii) compare the success of this sensor in developing $\mathrm{N}$ recommendations for maize to more conventional methods (PSNT and SPAD), for 21 different field site - years in Pennsylvania, USA.

\section{Materials and methods}

Maize was grown in a total of 21 farmers' fields between 2007 and 2009, located in east central and southeastern Pennsylvania (Table 1). Previous crop at each of these sites was either maize or soybean (Glycine Max L. Merr.) with notill (i.e. no tillage) as the standard tillage practice. Except for $\mathrm{N}$ fertilizer application, local management practices typical for maize production were followed.

At each site, eight $\mathrm{N}$ treatments were arranged in a randomized complete block design with four blocks. Nitrogen treatments included: 0 (control), 45, 90, 135, 180, 225, and $280 \mathrm{~kg} \mathrm{~N} \mathrm{ha}^{-1}$ applied at the V6-V7 growth stage (6th-7th fully mature leaf); and $280 \mathrm{~kg} \mathrm{~N} \mathrm{ha}^{-1}$ applied immediately after planting (high $\mathrm{N}$ reference). These treatments were adjusted slightly at one site, PC3 (2007), because the farmer had inadvertently applied $45 \mathrm{~kg} \mathrm{~N} \mathrm{ha}^{-1}$ at planting, so additionally including: $0,22,45,67,135,180$, and 225 applied at V6-V7; and $280 \mathrm{~kg} \mathrm{~N} \mathrm{ha}^{-1}$ applied immediately after planting. Nitrogen was broadcast applied by hand between the rows as $\mathrm{NH}_{4} \mathrm{NO}_{3}$ in 2007 and as urea in 2008 and applied as liquid 30\% urea-ammonium-nitrate (UAN) with Agrotain+ (Agrotain International, St. Louis, MO) in 2009. Plots were 4.6-m wide by 9.1-m long (six 0.76-m wide rows).

Preplant soil samples consisted of five 10-cm-diam. cores (openfaced auger) or 15 2-cm-diam. cores (step tube-type probe), $0-15-\mathrm{cm}$ deep, collected at planting. Samples from all four blocks were composited and a subsample retained, air dried, and ground to pass a $2-\mathrm{mm}$ sieve. Soil $\mathrm{pH}, \mathrm{P}, \mathrm{K}$, and organic matter content were determined by the agricultural analytical services laboratory (AASL; http://www.aasl.psu.edu; verified 8 September 2010). Details about the AASL analytical methods were provided by Dellinger et al. (2008).

Soil samples for PSNT were collected at V6-V7 from each control treatment $(n=4)$. Samples consisted of two $10-\mathrm{cm}$ - or six $2-\mathrm{cm}-$ diam. cores from 0 to $30-\mathrm{cm}$ deep. A subsample was retained, air dried, and ground to pass a 2-mm sieve.

To determine inorganic soil $\mathrm{N}, 10 \mathrm{~g}$ of soil were shaken in an Erlenmeyer flask with $50 \mathrm{~mL}$ of $2 \mathrm{M} \mathrm{KCl}$ for $30 \mathrm{~min}$ at $200 \mathrm{rpm}$, filtered through a Whatman No. 2 filter paper, and analyzed for $\mathrm{NH}_{4}-\mathrm{N}$ and $\mathrm{NO}_{3}-\mathrm{N}$ using flow injection analysis (QuickChem Method 10-107-04-1-A; Lachat Instruments, Milwaukee, WI).

Canopy reflectance data were collected at V6-V7 ( $\approx 16-30$ June) using a Crop Circle ACS-210 sensor (Holland Scientific, Lincoln, NE). The ACS-210 measures reflectance at $590\left(\mathrm{VIS}_{590}\right)$ and $880\left(\mathrm{NIR}_{880}\right)$ $\mathrm{nm}$ from light emitted by a modulated polychromatic Light Emitting Diode (LED) array, so is considered an "active" sensor. The sensor was carried on a pole approximately $60-\mathrm{cm}$ above and perpendicular to the maize leaf canopy. Reflectance was measured at a $6 \mathrm{~Hz}$ rate from one row in each plot (row three of six rows), providing $\approx 40$ measurements per plot. A Trimble Pro XRS Global Positioning System (GPS) receiver (Trimble Navigation Limited, Sunnyvale, CA) and Trimble TSCe field computer (Trimble Navigation Limited, Sunnyvale, CA) were used to simultaneously record the location of each reflectance measurement. All reflectance measurements outside a 1-m buffer inside the plot boundary were discarded, and the mean reflectance $(n \approx 40)$ was assigned to each plot. The amber normalized difference vegetative index (ANDVI) was determined for each plot based on the following equation (Eq. (1); referred to as GNDVI by Dellinger et al., 2008).

$A N D V I=\frac{\mathrm{NIR}_{880}-\mathrm{VIS}_{590}}{\mathrm{NIR}_{880}+\mathrm{VIS}_{590}}$

Relative ANDVI for each field site was determined based on the means $(n=4)$ of the control and reference $\left(280 \mathrm{~kg} \mathrm{Nha}^{-1}\right)$ treatments (Eq. (2)).

$\mathrm{ANDVI}_{\text {relative }}=\frac{\text { ANDVI }_{\text {control }}}{\mathrm{ANDVI}_{\text {reference }}}$

Chlorophyll meter (SPAD) measurements were collected using a Minolta SPAD-502 (Minolta Corp., Ramsey, NJ) from each of the control and at-planting $280 \mathrm{~kg} \mathrm{~N} \mathrm{ha}^{-1}$ (high $\mathrm{N}$ reference) treatments. Measurements were taken from six population-representative 
Table 1

Geographic location, selected soil characteristics, and grain yield at EONR for each field site.

\begin{tabular}{|c|c|c|c|c|c|c|c|c|c|c|c|}
\hline \multirow{3}{*}{$\begin{array}{l}\text { Year } \\
\text { Site }\end{array}$} & \multicolumn{2}{|c|}{ Geographic location } & \multirow[t]{3}{*}{ Previous crop ${ }^{\mathrm{a}}$} & \multirow[t]{3}{*}{ Dominant soil type ${ }^{b}$} & \multicolumn{6}{|c|}{ Initial soil characteristics, $0-15 \mathrm{~cm}$ depth } & \multirow{3}{*}{$\begin{array}{l}\text { Grain yield at } \\
\text { EONR }^{\mathrm{e}} \\
\mathrm{Mg} \mathrm{ha}^{-1}\end{array}$} \\
\hline & \multirow[t]{2}{*}{ North } & \multirow[t]{2}{*}{ West } & & & & $\mathrm{pH}$ & M3-Pd & M3-K ${ }^{\mathrm{d}}$ & $\mathrm{NO}_{3}-\mathrm{N}$ & $\mathrm{NH}_{4}-\mathrm{N}$ & \\
\hline & & & & & \multicolumn{2}{|c|}{$\mathrm{g} \mathrm{kg}^{-1}$} & \multicolumn{4}{|c|}{$\mathrm{mg} \mathrm{kg}^{-1}$} & \\
\hline \multicolumn{12}{|l|}{2007} \\
\hline PC1 & $40^{\circ} 49^{\prime} 33^{\prime \prime}$ & $77^{\circ} 05^{\prime} 18^{\prime \prime}$ & $\mathrm{S}$ & Berks shaly SiL & 30 & 7.1 & 25 & 149 & 7.9 & 3.3 & 2.6 \\
\hline PC2 & $40^{\circ} 49^{\prime} 22^{\prime \prime}$ & $77^{\circ} 06^{\prime} 32^{\prime \prime}$ & $\mathrm{S}$ & Shelmadine SiL & 24 & 6.9 & 75 & 101 & 11.1 & 7.4 & 7.0 \\
\hline PC3 & $40^{\circ} 51^{\prime} 12^{\prime \prime}$ & $77^{\circ} 03^{\prime} 46^{\prime \prime}$ & S & Alvira SiL & 26 & 6.9 & 34 & 117 & 3.3 & 1.7 & 7.3 \\
\hline K1 & $40^{\circ} 42^{\prime} 03^{\prime \prime}$ & $76^{\circ} 34^{\prime} 17^{\prime \prime}$ & C & Basher SiL & 22 & 4.9 & 82 & 76 & 4.4 & 3.7 & 6.6 \\
\hline K2 & $40^{\circ} 42^{\prime} 14^{\prime \prime}$ & $76^{\circ} 34^{\prime} 09^{\prime \prime}$ & $\mathrm{C}$ & Leck kill channery SiL & 31 & 7.2 & 220 & 186 & 4.7 & 4.1 & 5.5 \\
\hline \multicolumn{12}{|l|}{2008} \\
\hline PC1 & $40^{\circ} 49^{\prime} 21^{\prime \prime}$ & $77^{\circ} 04^{\prime} 38^{\prime \prime}$ & $\mathrm{S}$ & Hartleton channery SiL & 28 & 6.2 & 103 & 163 & 10.4 & 3.9 & 9.3 \\
\hline S1 & $40^{\circ} 49^{\prime} 00^{\prime \prime}$ & $76^{\circ} 52^{\prime} 35^{\prime \prime}$ & $\mathrm{C}$ & Monongahala SiL & 17 & 6.2 & 99 & 106 & 5.5 & 3.3 & 11.4 \\
\hline $\mathrm{S} 2$ & $40^{\circ} 49^{\prime} 07^{\prime \prime}$ & $76^{\circ} 52^{\prime} 24^{\prime \prime}$ & C & Monongahala SiL & 21 & 6.7 & 87 & 107 & 7.3 & 4.4 & 10.3 \\
\hline K1 & $40^{\circ} 42^{\prime} 13^{\prime \prime}$ & $76^{\circ} 33^{\prime} 53^{\prime \prime}$ & $\mathrm{C}$ & Atkins SiL & 17 & 7.2 & 39 & 77 & 11.3 & 6.9 & 10.2 \\
\hline K2 & $40^{\circ} 42^{\prime} 20^{\prime \prime}$ & $76^{\circ} 33^{\prime} 52^{\prime \prime}$ & $\mathrm{C}$ & Meckesville L & 23 & 5.4 & 37 & 56 & 9.9 & 9.1 & 8.0 \\
\hline MJ1 & $40^{\circ} 09^{\prime} 07^{\prime \prime}$ & $76^{\circ} 30^{\prime} 04^{\prime \prime}$ & C & Bedington SiL & 35 & 6.5 & 576 & 264 & 15.2 & 2.8 & 10.6 \\
\hline MJ2 & $40^{\circ} 05^{\prime} 07^{\prime \prime}$ & $76^{\circ} 32^{\prime} 39^{\prime \prime}$ & $\mathrm{S}$ & Duffield SiL & 24 & 6.6 & 365 & 364 & 19.4 & 2.4 & 11.9 \\
\hline L1 & $40^{\circ} 06^{\prime} 47^{\prime \prime}$ & $76^{\circ} 15^{\prime} 18^{\prime \prime}$ & S & Hagerstown SiL & 29 & 7.1 & 440 & 331 & 5.3 & 2.6 & 11.7 \\
\hline $\mathrm{L} 2$ & $40^{\circ} 07^{\prime} 13^{\prime \prime}$ & $76^{\circ} 25^{\prime} 27^{\prime \prime}$ & S & Hagerstown SiL & 24 & 6.9 & 137 & 264 & 7.4 & 2.6 & 10.2 \\
\hline L3 & $40^{\circ} 07^{\prime} 12^{\prime \prime}$ & $76^{\circ} 25^{\prime} 28^{\prime \prime}$ & $\mathrm{C}$ & Duffield SiL & 22 & 6.4 & 62 & 104 & 5.5 & 4.5 & 10.0 \\
\hline \multicolumn{12}{|l|}{2009} \\
\hline MJ1 & $40^{\circ} 03^{\prime} 59^{\prime \prime}$ & $76^{\circ} 29^{\prime} 33^{\prime \prime}$ & C & Hagerstown SiL & 20 & 6.6 & 148 & 157 & 5.2 & 1.8 & 13.3 \\
\hline MJ2 & $40^{\circ} 04^{\prime} 36^{\prime \prime}$ & $76^{\circ} 32^{\prime} 53^{\prime \prime}$ & $\mathrm{S}$ & Duffield SiL & 21 & 6.4 & 364 & 442 & 21.2 & 8.9 & 13.1 \\
\hline L1 & $40^{\circ} 06^{\prime} 55^{\prime \prime}$ & $76^{\circ} 15^{\prime} 15^{\prime \prime}$ & $\mathrm{S}$ & Hagerstown SiL & 25 & 7.2 & 489 & 460 & 5.9 & 2.8 & 12.7 \\
\hline $\mathrm{L} 2$ & $40^{\circ} 07^{\prime} 25^{\prime \prime}$ & $76^{\circ} 25^{\prime} 30^{\prime \prime}$ & $\mathrm{S}$ & Hagerstown SiL & 22 & 6.4 & 126 & 181 & 5.9 & 3.1 & 12.7 \\
\hline L3 & $40^{\circ} 07^{\prime} 30^{\prime \prime}$ & $76^{\circ} 25^{\prime} 28^{\prime \prime}$ & $\mathrm{C}$ & Hagerstown SiL & 17 & 6.5 & 149 & 156 & 7.5 & 3.6 & 12.9 \\
\hline $\mathrm{S} 1$ & $40^{\circ} 49^{\prime} 13^{\prime \prime}$ & $76^{\circ} 52^{\prime} 35^{\prime \prime}$ & C & Monongahala SiL & 24 & 6.8 & 219 & 178 & 15.1 & 4.2 & 12.4 \\
\hline
\end{tabular}

a $\mathrm{S}=$ soybean; $\mathrm{C}=$ corn.

b USDA-NRCS soil survey (verified 3 May 2010, http://websoilsurvey.nrcs.usda.gov/app/WebSoilSurvey.aspx). SiL=silt loam; L=loam.

c $\mathrm{OM}=$ organic matter content.

d Phosphorus and K were determined using the Mechlich-3 method and an inductively coupled plasma spectrophotometer.

e $E O N R=$ economic optimum nitrogen rate.

plants from the centre two rows of each plot when the majority of maize plants were at V7. A mean of the six measurements represented the SPAD value for each plot. As described by Beegle (2008a), measurements were taken from the fifth leaf, three quarters of the leaf length from the stalk, and about $1.5 \mathrm{~cm}$ from the edge of the leaf. The SPAD measurements were only taken at five of the ten sites in 2008 (first five sites in 2008 listed in Table 1 were omitted). Similar to the ANDVI values (i.e. Eq. (2)), relative SPAD values were calculated from the means $(n=4)$ of the control (zero $N)$ and high $\mathrm{N}$ reference treatments.

Plant biomass was determined for the control and high $\mathrm{N}$ reference treatments at V6-V7 by clipping the above-ground biomass of a 2-m length of row from rows one or six of the six-row plot.
Samples were dried at $70^{\circ} \mathrm{C}$ and weighed. Relative biomass was determined based on the same treatments as used to calculate $\mathrm{ANDVI}_{\text {relative }}$ (Eq. (2)), dividing biomass from the control by biomass from the high $\mathrm{N}$ reference.

Grain yield was determined based on the entire length $(9.1 \mathrm{~m})$ of the middle two rows in each plot; hand harvested, shelled, and weighed or harvested with a combine modified for small plots and fitted with a moisture sensor and weigh bucket. Yield was adjusted to $155 \mathrm{~g} \mathrm{~kg}^{-1}$ moisture content. Estimates of maize $\left(\$ 98.0 \mathrm{M} \mathrm{g}^{-1}\right.$ or $\left.\$ 2.50 \mathrm{bu}^{-1}\right)$ and fertilizer $\left(\$ 0.82[\mathrm{~kg} \mathrm{~N}]^{-1}\right.$ or $\left.\$ 0.37[\mathrm{lb} \mathrm{N}]^{-1}\right)$ prices were used with the quadratic-plateau yield response functions to calculate the economic return to $\mathrm{N}$ fertilizer as a function of $\mathrm{N}$ fertilizer rate for each field site. The EONR was determined as the a Previous study

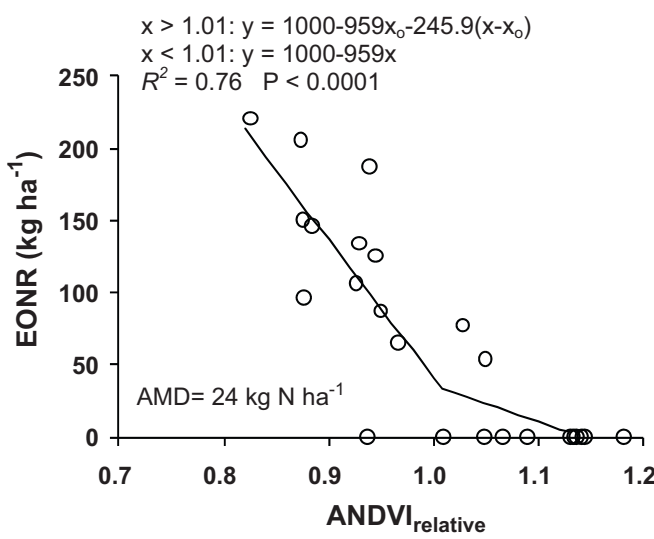

b Current study

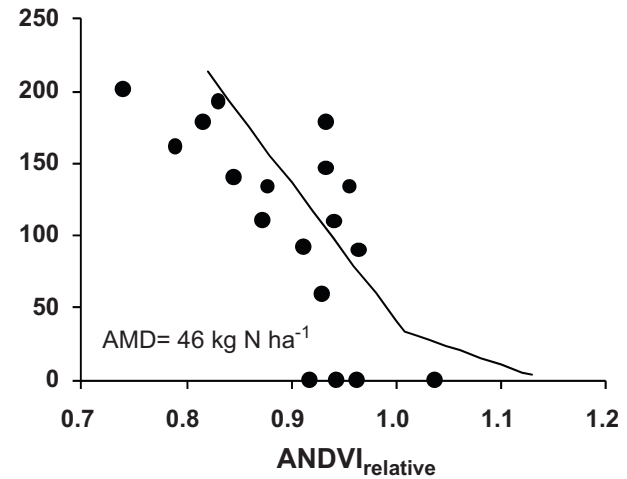

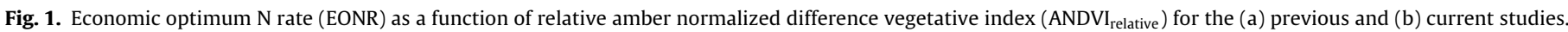
The regression line was determined based on data from the previous study (a). 
a Previous study

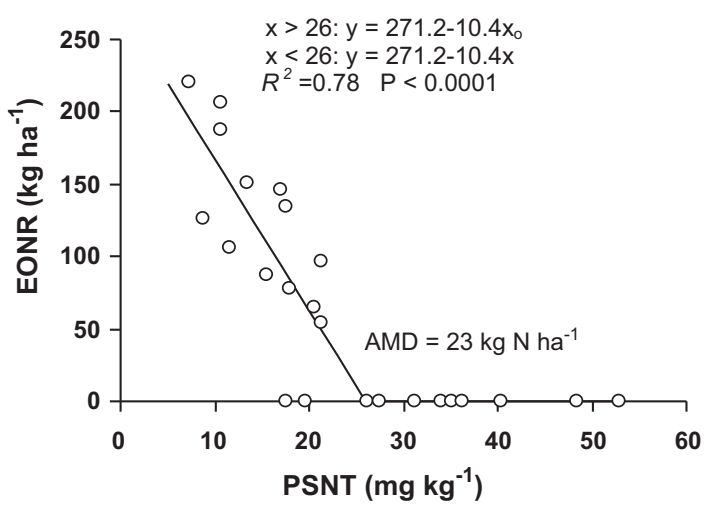

b Current study

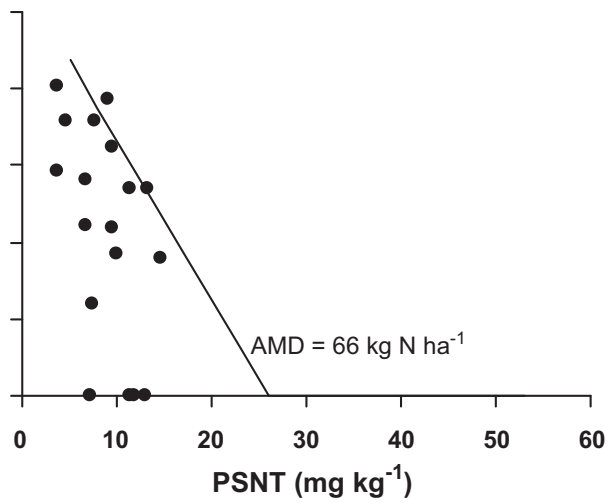

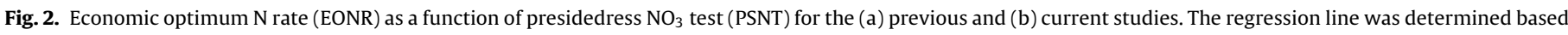
on data from the previous study (a).

$\mathrm{N}$ rate corresponding to maximum return based on these prices. If a quadratic-plateau yield response was not statistically significant $(\alpha=0.05$ ), the mean yield for each increasing $\mathrm{N}$ treatment was compared to the mean yield for all greater $\mathrm{N}$ treatments. This comparison of mean yields continued with each increasing $\mathrm{N}$ treatment until a significant difference was not detected. The smallest $\mathrm{N}$ treatment in this final comparison was selected as the EONR (Sripada et al., 2008).

PROC NLIN or PROC REG (SAS Institute Inc., Cary, NC) was used to fit a split-line, linear-plateau, and quadratic-plateau or linear regressions for various dependent and independent variables, including: EONR, grain yield, $\mathrm{ANDVI}_{\text {relative, }}$, relative biomass, SPAD relative, and PSNT. The $R^{2}$ for the split-line, linear-plateau, and quadratic-plateau regressions were determined as the $R^{2}$ for a linear regression between predicted vs. observed values.

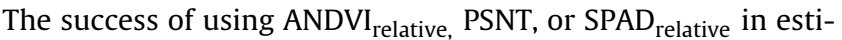
mating EONR from the current study was based on a comparison to the algorithms for the same relationships developed from the previous study (Dellinger et al., 2008; Schmidt et al., 2009), using the sum of the absolute mean differences (AMD) between EONR observed in the current study and previously determined regression equations. Details of the previous study are provided by Dellinger et al. (2008) and Schmidt et al. (2009), but a brief description is provided here.

Similar N treatments and methods as already described in the current study were used in the previous study to determine EONR,

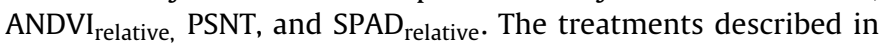
the current study corresponded to split plot treatments in the previous study, and whole plot treatments in the previous study included a control of $0 \mathrm{~kg} \mathrm{Nha}^{-1}, 56 \mathrm{~kg} \mathrm{Nha}^{-1}$ as $\mathrm{NH}_{4} \mathrm{NO}_{3}$, and $37-122 \mathrm{~kg} \mathrm{ha}^{-1}$ of available $\mathrm{N}$ (range among fields) as dairy manure, applied within 7 days before planting. The previous study included eight sites in 2 years within a small geographic region (within $<20 \mathrm{~km}$ distance; Centre County, Pennsylvania, USA). The previous crop varied among sites, including maize, soybean, or alfalfa (Medicago sativa L.). The combination of the varied previous crops and whole plot treatments provided a broad range of EONRs $(n=24)$

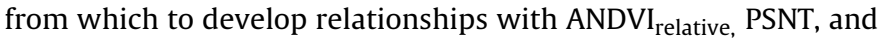

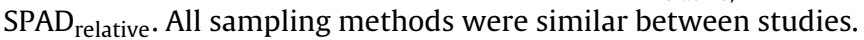

\section{Results and discussion}

The dominant soil types for each of the 21 sites selected in farmers' fields from east central and southeastern Pennsylvania, USA, included various silt loams, except for loam soils at one site in 2008 (Table 1). General soil characteristics reflected typical conditions of the maize producing regions of Pennsylvania, USA. Soil OM con- tent ranged from 17 to $35 \mathrm{~g} \mathrm{~kg}^{-1}$; $\mathrm{pH}$ from 4.9 to 7.2 ; soil test $\mathrm{P}$ from 25 to $576 \mathrm{mg} \mathrm{kg}^{-1}$; and soil test $\mathrm{K}$ from 56 to $460 \mathrm{mg} \mathrm{kg}^{-1}$ (Table 1). Preplant inorganic $\mathrm{NO}_{3}$ and $\mathrm{NH}_{4}$ were between 3.3 and $21.2 \mathrm{mg} \mathrm{NO}_{3}-\mathrm{N} \mathrm{kg}^{-1}$ and 1.7 and $9.1 \mathrm{mg} \mathrm{NH}_{4}-\mathrm{N} \mathrm{kg}^{-1}$. While the soil characteristics were sometimes less than optimum (e.g., soil $\mathrm{pH}=4.9$ or soil test $P=25 \mathrm{mg} \mathrm{kg}^{-1}$ ), these farmers' fields provided realistic conditions for testing these technologies.

\subsection{EONR is correlated to $A N D V I_{\text {relative }}, P S N T$, and $S P A D_{\text {relative }}$}

The relationship between EONR and ANDVI ${ }_{\text {relative }}$ from the previous study (Dellinger et al., 2008) was developed based on yield responses from 24 site-year-preplant treatment combinations during 2005 and 2006. Without preplant fertilizer or when manure was applied before planting, EONR was strongly related to $\operatorname{ANDVI}_{\text {relative }}\left(R^{2}=0.84\right)$ in a split-line type relationship, decreas-

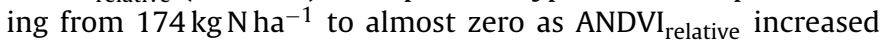
from 0.85 to 1.0 (Dellinger et al., 2008). Using the same data and including the third preplant treatment $\left(56 \mathrm{~kg} \mathrm{~N} \mathrm{ha}^{-1}\right)$ in the regression analysis, the relationship between EONR and ANDVI relative was $_{\text {. }}$ still strong $\left(R^{2}=0.76\right.$, Fig. 1a). These results, while encouraging and representing a broad range of management practices (e.g. maize after soybean, maize, or alfalfa; a history of regular manure applications or none; no fertilizer or $56 \mathrm{~kg} \mathrm{~N} \mathrm{ha}^{-1}$ applied before planting or manure applied before planting), represented a relatively small geographic region; so the current study focused on extending this work to other maize producing regions of Pennsylvania, USA.

Because there were fewer field sites in the current study where $\mathrm{EONR}=0$, fitting a split-line regression for the relationship between EONR and ANDVI relative was not possible (i.e. too few data points for $\mathrm{ANDVI}_{\text {relative }}>1.0$ to adequately define the right side of the split line). This was a consequence of selecting farmer fields where maize followed a previous crop of soybean or maize and not selecting fields where the previous crop was alfalfa or other forages. However, a comparison to the relationship developed in the earlier study (Fig. 1a) was possible. The measure of success was based on the difference between the observed EONR in the current study and the regression equation (EONR vs. ANDVI relative $_{\text {) from the previous }}$ study.

Currently, PSNT and SPAD are used in Pennsylvania for making $\mathrm{N}$ recommendations for maize based on methods provided by The Pennsylvania State University (Beegle et al., 1999; Beegle, 2008a). Based on results from the previous study, ANDVI $_{\text {relative }}$ was as good or better an indicator of EONR as either of these two commonly used tests (Schmidt et al., 2009; note that they referred to ANDVI relative as $\mathrm{GNDVI}_{\text {relative }}$ ). A linear relationship between EONR and PSNT- 

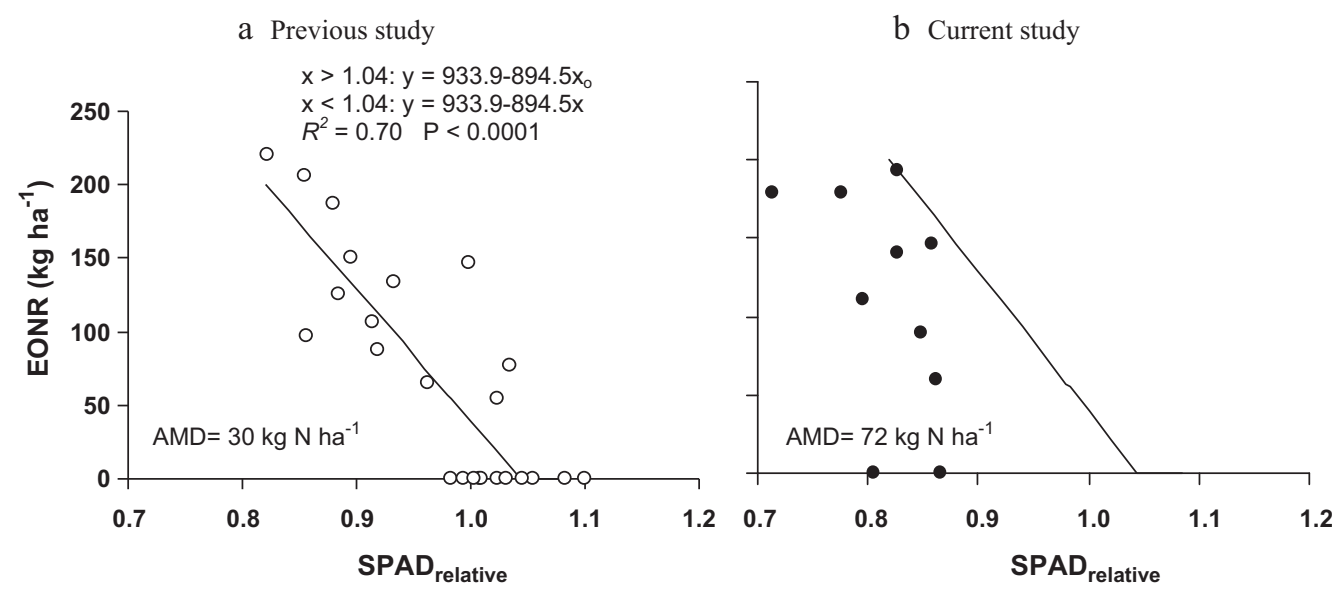

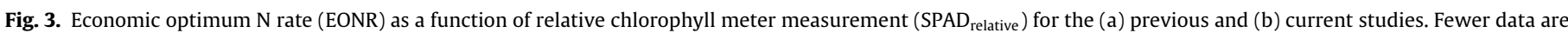

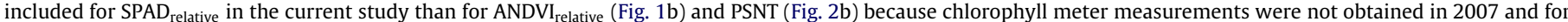
the first five sites in 2008 listed in Table 1. The regression line was determined based on data from the previous study (a).

based $\mathrm{N}$ recommendations was significant $(P=0.0002)$, but there was not a significant relationship between EONR and SPAD-based $\mathrm{N}$ recommendations (Schmidt et al., 2009). Because there currently does not exist an algorithm for making $\mathrm{N}$ recommendations based on ANDVI $_{\text {relative }}$, a direct comparison was not possible between $\mathrm{N}$ recommendations based on PSNT or SPAD and N recommendations based on ANDVI $_{\text {relative. }}$ However, a comparison of the relationships between EONR and PSNT, SPAD, or ANDVI relative $_{\text {provides an evalu- }}$ ation of the success these various methods would have for making $\mathrm{N}$ recommendations under the conditions of the current study. The AMD between the predicted and observed EONR for data from only the previous study was $24 \mathrm{~kg} \mathrm{Nha}^{-1}$ (Fig. 1a). This represented a good relationship and was comparable (Schmidt et al., 2009) to one of the best indicators available for making sidedress $\mathrm{N}$ recommendations for maize (i.e. AMD $=23 \mathrm{~kg} \mathrm{~N} \mathrm{ha}^{-1}$ for EONR vs. PSNT; Fig. 2a). The AMD between observations from the current study and the regression equation from the previous study was $46 \mathrm{~kg} \mathrm{~N} \mathrm{ha}^{-1}$ (Fig. 1b), which is $22 \mathrm{~kg} \mathrm{~N} \mathrm{ha}^{-1}$ greater for these fields representing a larger geographic region in Pennsylvania than observed for the study sites confined to Centre County, Pennsylvania (Fig. 1a). However, this measure of deviation was constrained with an upper threshold of $225 \mathrm{~kg} \mathrm{Nha}^{-1}$ for predicted EONR. This constraint, regardless of the value for $\mathrm{ANDVI}_{\text {relative, }}$ confined the hypothetical sidedress $\mathrm{N}$ application to less than or equal to $225 \mathrm{~kg} \mathrm{~N} \mathrm{ha}^{-1}$, which would be a realistic (conservatively high) constraint for sidedressing $\mathrm{N}$ to maize in Pennsylvania.
To determine whether PSNT performed as well as an indicator for EONR in the current study as the previous study, AMD between the previously determined regression equation and observed EONR was evaluated similarly as with ANDVI $_{\text {relative. In the previous }}$ study, PSNT was as good an indicator of EONR $\left(R^{2}=0.78\right.$ and

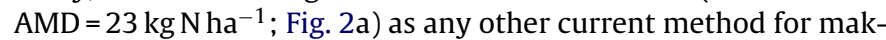
ing $\mathrm{N}$ recommendations for maize in Pennsylvania (Schmidt et al.

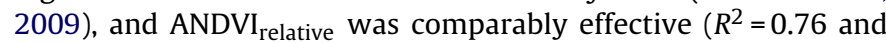
$\mathrm{AMD}=24 \mathrm{~kg} \mathrm{~N} \mathrm{ha}^{-1}$; Fig. 1a). The AMD increased from $23 \mathrm{~kg} \mathrm{~N} \mathrm{ha}^{-1}$ for the previous study (Fig. 2a) to $66 \mathrm{~kg} \mathrm{Nha}^{-1}$ for the current study (Fig. 2b). This represents an almost 3-fold increase in AMD,

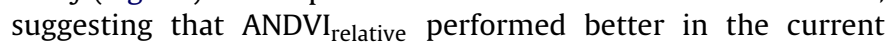
study ( $A M D=46 \mathrm{~kg} \mathrm{Nha}^{-1}$, Fig. $1 \mathrm{~b}$ ) than one of the best currently used methods for making $\mathrm{N}$ recommendation for maize, PSNT.

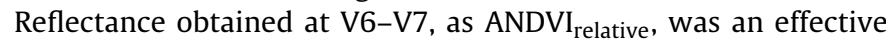
indicator for EONR and provides a greater opportunity to address spatial and temporal requirements in $\mathrm{N}$ availability than using a soil test such as PSNT.

The relationship between EONR and $S P A D_{\text {relative }}$ in the previous study was quite strong $\left(R^{2}=0.70, A M D=30 \mathrm{~kg} \mathrm{~N} \mathrm{ha}^{-1} ;\right.$ Fig. 3a) and comparable to the relationships between EONR and ANDVI relative (Fig. 1a) or PSNT (Fig. 2a). However, the AMD increased to $72 \mathrm{~kg} \mathrm{~N} \mathrm{ha}^{-1}$ for the current study (Fig. 3b), which was greater than a 3-fold increase in AMD and indicated that $S P A D_{\text {relative }}$ did not perform as well as $A N D V I_{\text {relative }}\left(A M D=46 \mathrm{~kg} \mathrm{~N} \mathrm{ha}^{-1}\right)$ when considering the larger geographic region of the current study.
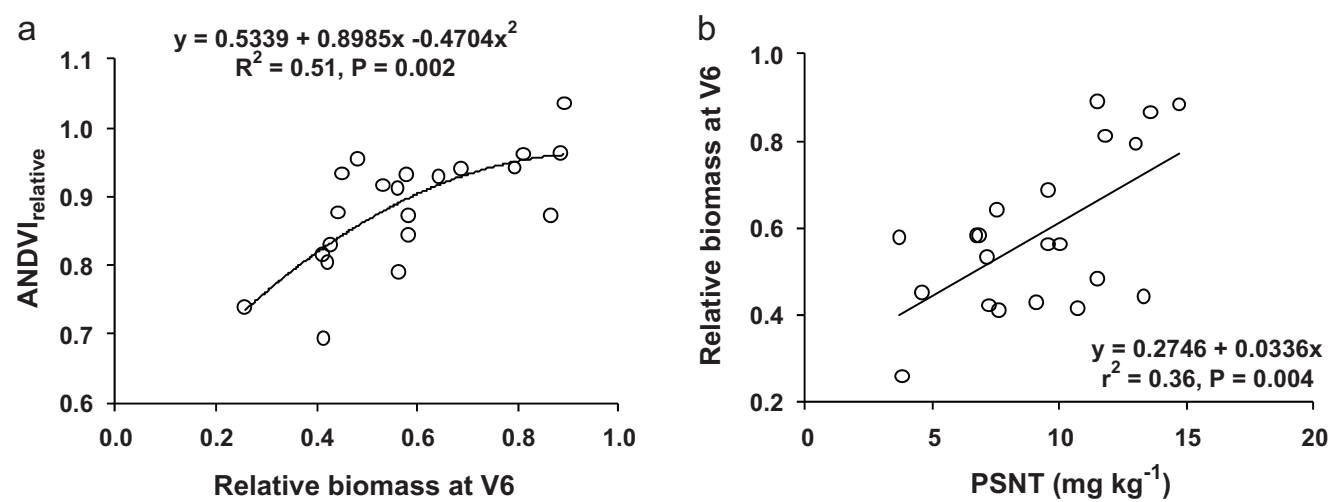

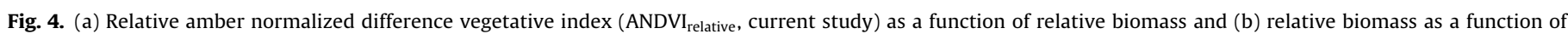
presidedress $\mathrm{NO}_{3}$ test (PSNT; current study). Measurements collected at V6-V7. 

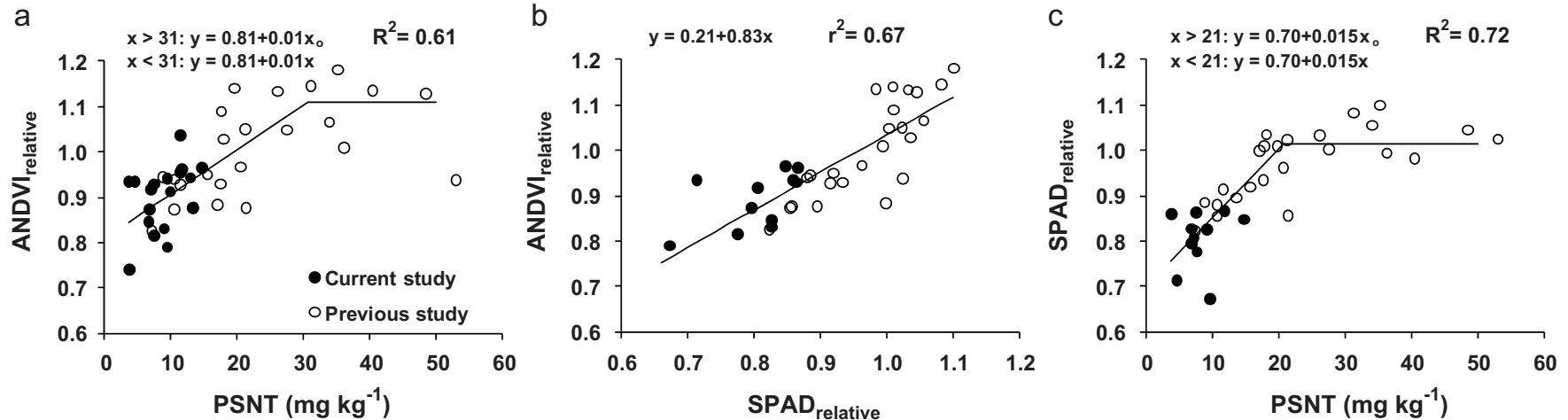

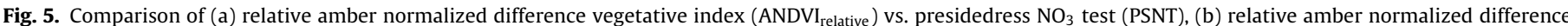

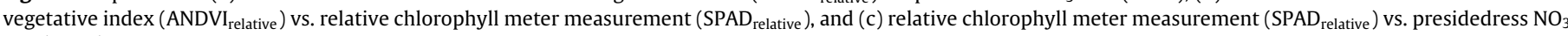
test (PSNT).

Numerous studies have evaluated whether these different methods (i.e., PSNT, canopy reflectance, and a chlorophyll meter) are effective in estimating $\mathrm{N}$ requirement or grain yield for maize. In evaluating the efficacy of PPNT and PSNT, Ma and Wu (2008) reported that PSNT was positively correlated with maize grain yield in eastern Ontario, Canada, and PSNT provided a better estimate of final grain yield than PPNT. Barbieri et al. (2008) showed that relative maize yield (yield compared to yield for the greatest $\mathrm{N}$ rate) was strongly related to PSNT $\left(R^{2}>0.68\right)$ for both conventional and narrow rows in Balcarce, Argentina. The chlorophyll meter was an effective tool for estimating the $\mathrm{N}$ rate difference from EONR $\left(R^{2}=0.73\right)$ for a wide range of soil and production conditions in Iowa (Hawkins et al., 2007). Solari et al. (2008) reported that a chlorophyll index also provided a good measure $\left(R^{2}=0.75\right)$ of relative maize yield, as did ANDVI $\left(R^{2}=0.76\right)$. A study similar to the current study was conducted in Missouri that showed that crop canopy reflectance was an effective indicator of optimal $\mathrm{N}$ rate in $50 \%$ of the fields evaluated (Kitchen et al., 2010). They also illustrated in the Missouri study that the value of using a crop canopy sensor increased as the fertilizer cost relative to maize grain price increased. Teal et al. (2006) evaluated the GreenSeeker (Ntech Industries, Ukiah, CA) canopy reflectance sensor and observed a strong relationship between NDVI (normalized difference vegetative index) at the V8 growth stage and maize yield in Oklahoma. These studies illustrate that the relationships between final grain yield and the measurements from these various tests are often quite good. However, more importantly, the relationship between EONR and these measurements is essential to developing appropriate $\mathrm{N}$ recommendation models. Studies have shown that EONR is not always related to grain yield (Fox and Piekielek, 1995; Vanotti and Bundy, 1994), so an explicit relationship between EONR and the specific indicator is essential to considering the success of the method for making $\mathrm{N}$ recommendations to maize.

\section{2. $A N D V I_{\text {relative }}$ is related to biomass and PSNT}

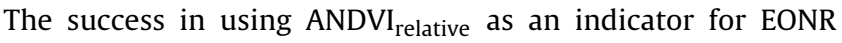
depends on whether the canopy reflectance information obtained at V6-V7 corresponds with maize $\mathrm{N}$ requirements for the entire growing season. The advantage to using an in-season indicator, such as reflectance obtained at V6-V7, is that the plant behaves as an integrator of conditions and stresses already experienced during the early growing season. If $\mathrm{N}$ stress is already present,

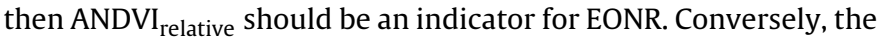
shortcoming of obtaining reflectance from maize at V6-V7 is that this growth stage occurs at the beginning of rapid $\mathrm{N}$ uptake, so $\mathrm{N}$ deficiency or mineralization that occur later in the growing season may not yet be expressed in the growing crop.
In the current study, ANDVI relative $_{\text {was }}$ related to relative biomass at V6-V7, increasing quadratically from 0.73 to 0.95 as relative biomass increased from 0.25 to $0.80\left(R^{2}=0.51\right.$, Fig. 4 a $)$. Relative biomass correspondingly increased linearly from 0.44 to 0.78 as PSNT increased from 5 to $15 \mathrm{mg} \mathrm{kg}^{-1}$, though not as strongly correlated $\left(R^{2}=0.36\right.$, Fig. $\left.4 \mathrm{~b}\right)$ as the relationship between ANDVI $\mathrm{I}_{\text {relative }}$ and relative biomass. These relationships (Fig. 4) suggest that ANDVI $_{\text {relative }}$ at $\mathrm{V} 6-\mathrm{V} 7$ is providing similar information as obtained with a PSNT. Because we have data from the current and previous studies for ANDVI $I_{\text {relative }}$ and PSNT, this relationship can also be

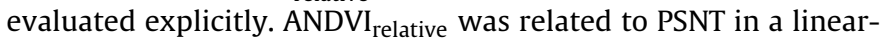
plateau type relationship $\left(R^{2}=0.60\right.$, Fig. 5a), increasing linearly from 0.8 to 1.1 as PSNT increased from 0 to $31 \mathrm{mg} \mathrm{kg}^{-1}$. When PSNT was greater than $31 \mathrm{mg} \mathrm{kg}^{-1} \mathrm{ANDVI}_{\text {relative }}$ remained constant at 1.1. In addition, $A N D V I_{\text {relative }}$ was related to $S P A D_{\text {relative }}$ in a linear relationship $\left(R^{2}=0.67\right.$, Fig. $\left.5 \mathrm{~b}\right)$ and $\mathrm{SPAD}_{\text {relative }}$ was related to $\mathrm{PSNT}_{\text {relative }}$ in a linear-plateau type relationship $\left(R^{2}=0.72\right.$, Fig. $\left.5 \mathrm{c}\right)$. These relationships (Fig. 5) suggest that crop growth at V6-V7, as measured by ANDVI $I_{\text {relative, provided similar information as }}$ obtained with a PSNT or SPAD relative. Based on results from the previous and current studies, ANDVI $\mathrm{I}_{\text {relative }}$ was a slightly better indicator of EONR than PSNT (Figs. 1 and 2). Additionally,

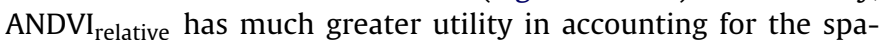
tial and temporal variability of $\mathrm{N}$ availability and requirements for maize.

\subsection{Practical implications}

When data from the previous study were combined with data

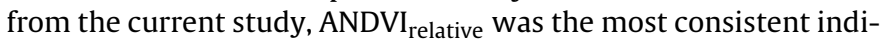

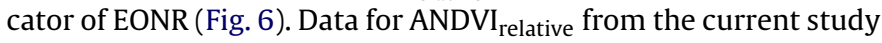
appeared to overlay data from the previous study and a significant $\left(R^{2}=0.65\right)$ split-line model could be fit through all the data (Fig. 6a). By contrast, the PSNT data from the current study seems to be shifted to smaller values (left) on the $x$-axis (Fig. 6b); however, a significant split-line model still represented the relationship between EONR and PSNT. A split-line model for EONR and SPAD relative could not be fit through the combined data of both studies (Fig. 6c). Compared to the fitted lines for the data from the previous study (2007 algorithm), the slopes of the relationships for data from both studies (2010 algorithm) were slightly less between EONR and ANDVI relative (Fig. 6a) or PSNT (Fig. 6b).

While there will always be variability of observations around the fitted line of a regression, there are a few noteworthy observations from Fig. 6. There are four observations when EONR was zero and

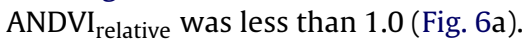

One of these observations in the current study (closed symbols) corresponded to a field site where rainfall was exceptionally low 
a

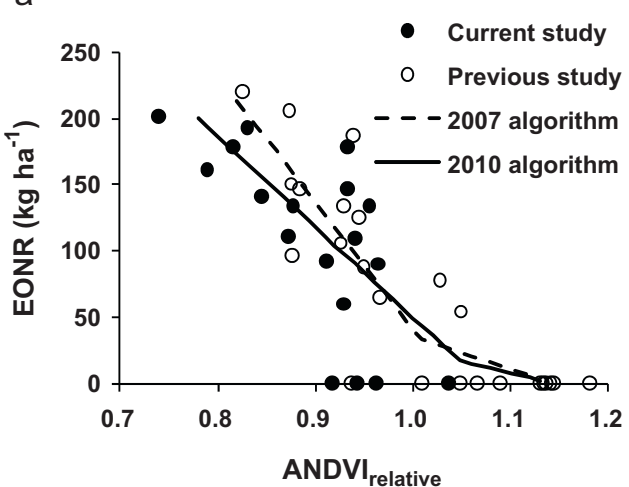

2010

$x>1.05: y=735.7-686.1 x_{0}-180.2\left(x-x_{0}\right)$

$x<1.05: y=735.7-686.1 x$ b
C

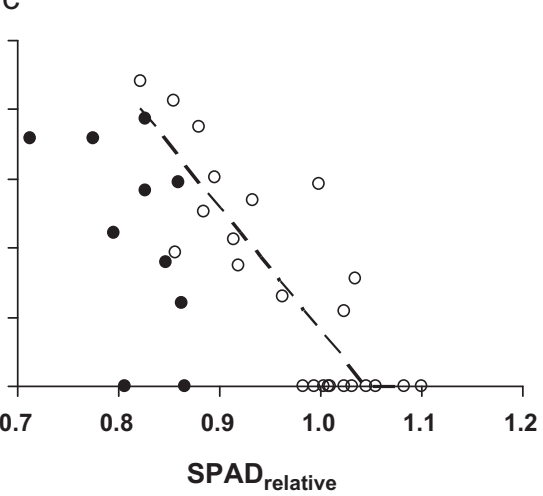

2010

$x>28.8: y=184.1-6.39 x_{0}$

$x<28.8: y=184.1-6.39 x$
2010

(could not fit a model)

$R^{2}=0.65, P<0.0001$

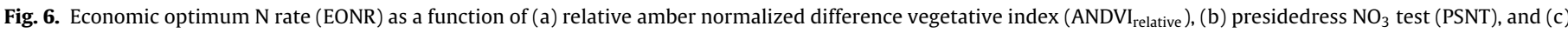

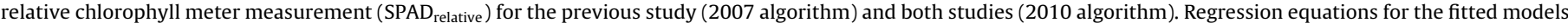
from the previous study can be found in Figs. 1-3.

throughout the year and maize leaves were distinctly whorled due to drought stress when measurements were collected at V6-V7. Mean grain yield at this site (PC1, 2007) was $2.6 \mathrm{Mg} \mathrm{ha}^{-1}$, much less than observed for any other site in 2007 (Table 1 ), though grain yield in 2007 reflected less than adequate rainfall at all sites that year. At this same site, PSNT was less than $15 \mathrm{mg} \mathrm{kg}^{-1}$, yet EONR was zero. This was also one of the sites where SPAD measurements were not obtained, so we do not know how well chlorophyll meter measurements (SPAD) might have performed, though all of these technologies appear to have failed because of the droughty conditions at PC1 (2007).

Two other observations from the current study (closed symbols) with EONR $=0$ corresponded with ANDVI relative $_{1 .}$ 1. PSNT $<15$, and $\mathrm{SPAD}_{\text {relative }}<0.9$ (Fig. 6). These two field sites were located on the same farm, but different fields, one each in 2007 and 2008. At the time of measurements (V6-V7), maize from the preplant $\mathrm{N}$ treatment was visually greener than maize in any of the treatments where $\mathrm{N}$ had not yet been applied, suggesting that a response to $\mathrm{N}$ should be observed here. However at harvest, the maize visually appeared similarly across $\mathrm{N}$ treatments and grain yield reflected the visual appearances. The EONR was zero both years. Mean grain yield at both of these sites (MJ2, 2007 and 2008) exceeded $11.9 \mathrm{Mg} \mathrm{ha}^{-1}$ (Table 1). These two fields were located in an area of Lancaster County, Pennsylvania that has had a long history of livestock production (Kogelmann et al., 2004), and these fields have probably received regular manure applications for many years (perhaps $100+$ ). Visual observations during the growing season suggest that mineralization after the V6-V7 growth stage contributed to the unusual lack of yield response to $\mathrm{N}$, and developing a $\mathrm{N}$ recommendation for maize with any of these technologies will be difficult unless an application can be delayed until later in the growing season. Research in North Carolina (Sripada et al., 2005) indicated that using remote sensing for making a $\mathrm{N}$ application to maize can be successful as late as the VT (tasseling) growth stage. Except in instances of severe stress attributed to something other than $\mathrm{N}$ (e.g. drought), and where presumably considerable lateseason (after V6-V7) N mineralization is occurring, the crop canopy reflectance information obtained at V6-V7 appears to be effective for estimating EONR. In this study, EONR was more closely related to ANDVI $_{\text {relative }}$ than either PSNT or SPAD relative (Fig. 6).

If we consider that both ANDVI $_{\text {relative }}$ and PSNT perform similarly in determining the correct $\mathrm{N}$ application, as results here suggest, there are a few key advantages to consider in using ANDVI $_{\text {relative }}$ for making $\mathrm{N}$ recommendations compared to using PSNT. A crop canopy sensor would be mounted on the front of the $\mathrm{N}$ applicator tractor (or other similar machine used for $\mathrm{N}$ application) simultaneously with when the $\mathrm{N}$ fertilizer is being applied. This provides an immediate evaluation of the $\mathrm{N}$ status for the growing crop. The farmer would not have to wait for soil analyses results from soil samples that would have been collected several days to 2 weeks before the date of $\mathrm{N}$ application. The PSNT requires 0 - to $30-\mathrm{cm}$ depth soil samples, which can also be difficult to obtain from stony or dry soils. Collecting soil samples sufficiently early to be used to make a sidedress $\mathrm{N}$ application also means that there is additional temporal uncertainty in the PSNT evaluation. Subsequent N mineralization or other changes in the soil $\mathrm{N}$ status between when soil samples are collected and when $\mathrm{N}$ is applied contributes to the additional temporal uncertainty of the PSNT results. The PSNT soil samples for the current study were collected at the same time as when $\mathrm{N}$ fertilizer was applied, so PSNT results here may have been more favorable than might be expected in a practical situation.

Spatial variability in maize $\mathrm{N}$ requirements can also be better managed using a canopy reflectance sensor. With soil samples (i.e. PSNT), an additional soil sample must be collected for every area of the field that is being considered for a different $\mathrm{N}$ application. For example, if $\mathrm{N}$ fertilizer is going to be applied based on information obtained from every 0.5 -ha area within a 20 -ha field, 40 soil samples would need to be collected and analyzed. This adds considerably to labor and analytical costs. While SPAD measurements can be collected immediately before a $\mathrm{N}$ application, thus addressing some of the temporal uncertainty in making $\mathrm{N}$ recommendations for maize, these measurements are collected one at a time and by hand, so are not conducive to spatially variable $\mathrm{N}$ applications. In addition, SPAD relative was not as good an indi-

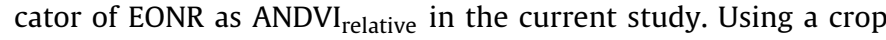
canopy reflectance sensor to manage small areas within a field might require additional high " $N$ reference" areas, similar to the $280 \mathrm{~kg} \mathrm{Nha}^{-1}$ preplant treatment in the current study, but this could be managed more easily than the additional soil samples required for a spatially variable $\mathrm{N}$ application. Additional sensor measurements to obtain sufficient information from throughout a field could be obtained relatively easily and timely with a few extra passes immediately before a $\mathrm{N}$ application. The crop canopy sensor information was as well correlated to EONR as was PSNT, but 
the temporal and spatial flexibility provided with the crop canopy sensor makes this an attractive approach for developing $\mathrm{N}$ recommendations for maize.

\section{Conclusion}

The current study extended the evaluation of using crop canopy reflectance, as an indicator for EONR, from Centre County, Pennsylvania, USA to 21 additional farmers' fields in east central and southeastern Pennsylvania. When compared to the success of PSNT and $S P A D_{\text {relative, }}$ currently two of the best tools for making $\mathrm{N}$ recommendations for maize in Pennsylvania, ANDVI $_{\text {relative }}$ obtained at the V6-V7 growth stage was just as effective (or better) an

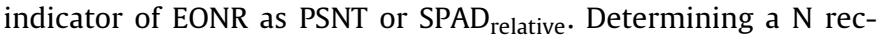
ommendation simultaneously with a sidedress $\mathrm{N}$ application using ANDVI $_{\text {relative }}$ provides the opportunity to adjust the $\mathrm{N}$ application spatially, depending on the relative crop demands and soil $\mathrm{N}$ availability, and to apply $\mathrm{N}$ fertilizer timely, consistent with matching crop demand and minimizing environmental risks.

\section{References}

Barbieri, P.A., Echeverria, H.E., Rozas, H.R.S., 2008. Presidedress soil nitrogen test for no-tillage maize at different row spacing. Agron. J. 100, 1101-1105.

Beegle, D.B., 2008a. The Early Season Chlorophyll Meter Test for Corn. Agronomy Facts, vol. 53. College of Agricultural Sci., Penn State Univ., University Park, PA.

Beegle, D.B., 2008b. Soil fertility management. In: Rudisill, A. (Ed.), Agronomy Guide. Penn State Univ., College of Agric. Sci., University Park, PA.

Beegle, D.B., Fox, R.H., Roth, G.W., Piekielek, W., 1999. Pre-sidedress Soil Nitrate Test for Corn. Agronomy Facts, vol. 17. University Park, PA, College of Agricultural Sci., Penn State Univ.

Blackmer, T.M., Schepers, J.S., Meyer, G.E., 1995. Remote sensing to detect nitrogen deficiency in corn. In: Robert, P.C., Rust, R.H., Larson, W.E. (Eds.), Proceedings of Site-specific Management for Agricultural Systems: Second International Conference. ASA-CSSA-SSSA. Minneapolis, MN, USA, pp. 505-511.

Blackmer, T.M., Schepers, J.S., 1996. Aerial photography to detect nitrogen stress in corn. J. Plant Physiol. 148, 440-444.

Buchholz, D., Brown, J.R., Hanson, R.G., 1993. Using Your Soil Test Results. Extension Publication G9111. Univ. of Missouri Extension, Columbia, MO, USA

Cassman, K.G., Doberman, A., Walters, D.T., 2002. Agroecosystems, nitrogen-use efficiency, and nitrogen management. Ambio 31, 132-140.

Dellinger, A.E., Schmidt, J.P., Beegle, D.B., 2008. Developing nitrogen fertilizer recommendations for corn using an active sensor. Agron. J. 100, 15461552.

Ferguson, R.B., Hergert, G.W., Schepers, J.S., Gotway, C.A., Cahoon, J.E., Peterson, T.A., 2002. Site-specific nitrogen management of irrigated maize: yield and soil residual nitrate effects. Soil Sci. Soc. Am. J. 66, 544-553.

Fox, R.H., Piekielek, W.P., 1995. The relationship between corn grain yield goals and economic optimum nitrogen fertilizer rates. Publication \#136. Crop and Soil Sciences Department, Pennsylvania State University, University Park, PA, USA
Hawkins, J.A., Sawyer, J.E., Baker, D.W., Lundvall, J.P., 2007. Using relative chlorophyll meter values to determine nitrogen application rates for corn. Agron. J. 99, 1034-1040.

Hong, N., Scharf, P.C., Davis, J.G., Kitchen, N.R., Sudduth, K.A., 2007. Economically optimal nitrogen rate reduces soil residual nitrate. J. Environ. Qual. 36, 354-362.

Kitchen, N.R., Sudduth, K.A., Drummond, S.T., Scharf, P.C., Palm, H.L., Roberts, D.F., Vories, E.D., 2010. Ground-based canopy reflectance sensing for variable-rate nitrogen corn fertilization. Agron. J. 102, 71-84.

Kogelmann, W.J., Lin, H.S., Bryant, R.B., Beegle, D.B., Wolf, A.M., Petersen, G.W., 2004. A statewide assessment of the impacts of P-index implementation in Pennsylvania. J. Soil Water Conserv. 59, 9-18.

Ma, B.L., Wu, T.Y., 2008. Plant-available nitrogen in the soil: relationships between pre-plant and pre-sidedress nitrate tests for corn production. J. Plant Nutr. Soil Sci. 171, 458-465.

Magdoff, F., 1991. Understanding the magdoff pre-sidedress nitrate test for corn. J. Prod. Agric. 4, 297-305.

Raun, W.R., Solie, J.B., Johnson, G.V., Stone, M.L., Mullen, R.W., Freeman, K.W., Thomason, W.E., Lukina, E.V., 2002. Improving nitrogen use efficiency in cereal grain production with optical sensing and variable rate application. Agron. J. 94, $815-820$

Sawyer, J., Nafziger, E., Randall, G., Bundy, L., Rehm, G., Joern, B., 2006. Concepts and Rationale for Regional Nitrogen Rate Guidelines for Corn. Extension Publication PM 2015. Iowa State University, Ames, IA, USA.

Scharf, P.C., Kitchen, N.R., Sudduth, K.A., Davis, J.G., Hubbard, V.C., Lory, J.A., 2005. Field-scale variability in optimal nitrogen fertilizer rate for corn. Agron. J. 97, 452-461.

Schmidt, J.P., Hong, N., Dellinger, A., Beegle, D.B., Lin, H.S., 2007. Hillslope variability in corn response to nitrogen linked to in-season soil moisture redistribution. Agron. J. 99, 229-237.

Schmidt, J.P., Dellinger, A.E., Beegle, D.B., 2009. Nitrogen recommendations for corn: an on-the-go sensor compared with current recommendation methods. Agron. J. 101, 916-924.

Schepers, J.S., Varvel, G.E., Watts, D.G., 1995. Nitrogen and water management strategies to reduce nitrate leaching under irrigated maize. J. Contam. Hydrol. 20, 227-239.

Shapiro, C.A., Ferguson, R.B., Hergert, G.W., Doberman, A.R., Wortman, C.S., 2003. Fertilizer Suggestions for Corn. Extension Publication G74-174-A. Univ. of Nebraska Cooperative Extension, Lincoln, NE, USA.

Solari, F., Shanahan, J., Ferguson, R., Schepers, J., Gitelson, A., 2008. Active sensor reflectance measurements of corn nitrogen status and yield potential. Agron. J. 100, 571-579.

Sripada, R.P., Heiniger, R.W., White, J.G., Weisz, R., 2005. Aerial color infrared photography for determining late-season nitrogen requirements in corn. Agron. J. 97, 1443-1451.

Sripada, R.P., Schmidt, J.P., Dellinger, A.E., Beegle, D.B., 2008. Evaluating multiple indices from a canopy reflectance sensor to estimate corn $\mathrm{N}$ requirements. Agron. J. 100, 1553-1561.

Teal, R.K., Tubana, B., Girma, K., Freeman, K.W., Arnall, D.B., Walsh, O., Raun, W.R., 2006. In-season prediction of corn grain yield potential using normalized difference vegetation index. Agron. J. 98, 1488-1494.

Vanotti, M.B., Bundy, L.G., 1994. An alternative rationale for corn nitrogen fertilizer recommendations. J. Prod. Agric. 7, 243-249.

Varvel, G.E., Schepers, J.S., Francis, D.D., 1997. Ability for in-season correction of nitrogen deficiency in corn using chlorophyll meters. Soil Sci. Soc. Am. J. 61, 1233-1239.

Zhu, Q., Schmidt, J.P., Lin, H.S., Sripada, R.P., 2009. Hydropedological processes and their implications for nitrogen availability to corn. Geoderma 154, 111-122. 